\title{
Algı Haritaları ve Marka Konumlandırma: Dizüstü Bilgisayar Markaları Üzerine Bir Çalışma
}

Hasan Hüseyin CEYLAN*

\section{Özet}

Markalar arası artan rekabetin bir sonucu olarak, tüketici zihninde rakiplere göre farklı bir yer edinme çabası olarak görülen marka konumlandırmanın önemi artmıştır. Bu çabanın ilk aşamasını, tüketicilerin markalara ilişkin mevcut algılarının belirlenmesi oluşturmaktadır. Tüketicilerin algı haritalarının belirlenmesi konumlandırma kararlarında yol gösterici olmaktadır.

Bu çalışmada, rekabetin yoğun olarak yaşandığı dizüstü bilgisayar markalarına ilişkin üniversite öğrencilerinin algı haritalarını belirlemek üzere metrik olmayan çok boyutlu ölçekleme analizi kullanılmıştır. Çalışma verileri, marka çiftlerine ilişkin benzerlik ve her bir markanın belirlenen özellikler üzerinden değerlendirilmesi ile elde edilmiştir. Analiz sonucunda fonksiyonel ve estetik özellikler olmak üzere iki boyut elde edilmiştir. Çalışmada yer alan dizüstü bilgisayar markaları, elde edilen boyutlar üzerinden değerlendirilmiştir.

Anahtar Kelimeler: Alg1 Haritaları, Marka Konumlandırma, Çok Boyutlu Ölçekleme Analizi

\section{Perceptual Maps and Brand Positioning: A Research on Laptop Brands}

\section{Abstract}

The importance of brand positioning, which is the effort of finding a different place in the minds of consumers than the rivals, increased as a result of the high competition between brands. To identify the current perception of the consumer forms the first phase of this effort. Identifying consumers' perceptual maps guides positioning decisions.

In this study multi-dimensional scaling analysis is used to identify the perceptual maps of university students on laptop markets where the competition is high. The data is obtained by evaluation of similarities of the brand pairs and evaluation of the certain features of the brands. Functional and aesthetic features are obtained as two dimensions in the end of analysis.

* Yrd. Doç. Dr.,Uşak Üniversitesi, İ.İ.B.F., İşletme Bölümü 
Uşak Üniversitesi Sosyal Bilimler Dergisi

$2013,6 / 3$

H. H. CEYLAN

In the research, laptop brands are evaluated in terms of these two dimensions.

Key Words: Perceptual Maps, Brand Positioning, multi-dimensional scaling

\section{Giriş}

Pek çok markanın kıyasıya rekabet ettiği günümüz pazar koşullarında işletmelerin başarılı olabilmeleri, farklılaştırabilme yeteneklerine bağlıdır. Pazarda birbirine çok benzer olarak algılanan markaların tüketiciler tarafından tercih edilme ihtimali düşüktür. Ancak markaların tüketiciler tarafından tercihinde, objektif kriterlere göre farklılıkları değil, tüketicilerin sübjektif değerlendirmeleri sonucu oluşan markalar arası algısal farklılıkları önem taşımaktadır (Kotler vd., 1999: 107108). Çünkü bireyler gerçeklere göre değil, algılarına göre tepki vermekte ve hareket etmektedir. Dolayısıyla pazarlama açısından gerçeklerden çok, tüketicilerin davranışlarını ve satın alma alışkanlıklarını etkileyen tüketici algıları daha büyük önem taşımaktadır (Schiffman ve Kanuk, 1994: 161). Nitekim Kotler ve Andreasen'e (1996: 72) göre pazarlama çabaları, tüketicilerin markalara ilişkin algıladıkları faydanın algıladıkları maliyetten alternatiflere kıyasla daha fazla olmasını sağlamaya dönük olmalıdır.

Dolayısıyla pazarlama yöneticileri açısından markalarının rakiplere göre tüketiciler tarafından nasıl algılandığının belirlenmesi büyük önem taşımaktadır. Bu konuda elde edilecek veriler; rekabetin yoğunluğu, rekabetin ne üzerinden yapıldığı, niş pazarların keşfedilmesi ve pazara sunulacak yeni ürünlerin olası etkileri konusunda pazarlama kararlarına çok önemli bilgiler sağlayabilir (Ghose, 1994: 5). Bu bilgiler 1şığında marka konumlandırma veya yeniden konumlandırma kararları daha isabetli olarak verilebilir. Markanın tüketicinin zihninde rakip markalara göre bulunduğu yer olarak tanımlanan konumlandırma ile markanın rakip markalardan farklılaşması sağlanmakta ve önemli stratejik rekabet avantajı elde edilebilmektedir (Kotler vd., 1999: 108).

\section{Marka Konumlandırma}

Pazarda başarılı olmak isteyen işletmeler için tüketici ihtiyaçlarını karşılamak gerekli ama yeterli değildir. İşletmelerin tüketici ihtiyaçlarını karşılamanın yanında rekabet avantajı sağlayacak faktörlere sahip olmaları gerekmektedir. Günümüz koşullarında rekabet avantajı elde etmenin yolu, işletmenin tüketicilere sunduğu pazarlama önerilerini rakiplerinkinden 
farklılaştırabilmelerinden geçmektedir. Bu amaçla işletmeler markalarını, rakiplerden farklılaştırıcı bir veya birkaç özelliğe dayalı olarak tüketici zihninde konumlandırmaya çalışmaktadırlar (Kotler vd., 1999: 107-108).

Aaker (1996: 176), marka konumlandırmayı "markanın rakip markalara olan üstünlüklerini gösteren ve aktif biçimde hedef pazara iletişimi yapılması gereken marka kimliği ve değer önerisinin bir parçası" olarak tanımlamaktadır. Bir başka çalışmada marka konumlandırma "markay1, tüketicilerin zihninde rakiplerden ayrıştırmak" şeklinde tanımlanmaktadır (Lepla ve Parker, 2002: 77).

Yukarıdaki tanımlar da dahil olmak üzere pazarlama yazınındaki marka konumlandırma tanımları incelendiğinde en fazla vurgulanan noktanın, rakiplerden farklılaşmak ve rakiplerden üstünlüklerini vurgulamak olduğu görülmektedir. Ciproano (2007: 79) tarafından da ifade edildiği gibi işletmeler markalarını, rakiplerden farklılaştırmak ve tüketicilerin kendi markalarını rakiplere göre daha iyi ve daha özel olarak tanımlamalarını sağlamak amacıyla konumlandırmaktadırlar. Nitekim Gelder de (2008: 31), marka konumlandırmanın başlangıcından günümüze çok farklı anlamlarda kullanıldığını, ancak kendisinin marka konumlandırmayı, markanın rakiplerden üstünlüklerini gösterme ve markayı rakiplerden farklılaştırma aracı olarak gördüğünü ifade etmiştir.

Markaların rakiplerinden farklılaşmaları önemlidir ama her farklılık değerli değildir. Pazarlama açısından farklılı̆̆ı aynı zamanda değerli olması için taşıması gereken bazı özellikler şunlardır (Kotler, 2002: 178):

- Önem: Farklılık yeteri sayıda tüketiciye yüksek değerde fayda sağlamalı

- Üstünlük: Farklılık, ilgili faydayı elde etmemin diğer yollarından daha üstün olmalı

- Taklit edilebilirlik: Farklılık rakipler tarafından kolayca taklit edilememeli

- Satın alınabilirlik: Tüketiciler, farklılığı ödeyebilir olmalı

- Karlılık: Farklılık, işletme açısından karlı olmalı

Marka konumlandırma tanımlarında ikinci önemli vurgu, marka konumlandırmanın tüketici zihninde gerçekleştirildiğidir. Aaker(1996)'in tanımda yer alan "aktif biçimde iletişimin yapılması" ifadesi, markaların sadece üstünlüklere ve farklılıklara sahip olmalarının yeterli olmayacağını, doğru iletişimin yapılmasının da en az farklılık ve üstünlükler kadar önemli olduğunu vurgulamaktadır. 
Marka konumlandırma, işletmelerin başarısı için bir gereklilik olmakla birlikte doğru planlanmayan marka konumlandırma süreci işletmeler için fayda yerine zarar getirebilir. $\mathrm{Bu}$ nedenle marka konumlandırma sürecinin planlanmasında dikkate alınması gereken bazı noktalar bulunmaktadır. Bunların en önemlileri; hedef pazar, markanın diğer markalardan ne kadar farklı veya daha iyi algılandığı, bu farklılığın hedef pazar açısından değerinin ne olduğu ve işletmenin, bu farklılıkların hedef pazara iletişimini yapma kabiliyeti olarak sayılabilir (Gwin ve Gwin, 2003: 31).

Konumlandırmanın tek özellik veya çok özellik üzerinden mi gerçekleştirileceği önemli konumlandırma kararlardan biridir. Çok özellik üzerinden yapılan konumlandırma çabalarının sonuçları belirli istisnalar dışında olumlu olmamaktadır. Çok özellikli konumlandırma stratejilerinde ortaya konulan iddialar, tüketiciler tarafından ya hatırlanmamakta ya da inanılmamaktadır (Kotler, 2003: 136).

Konumlandırma kararlarında bir diğer önemli nokta, konumlandırmada neyin temel alınacağıdır. Ürün özellikleri ve faydaları, konumlandırmada en fazla temel alınan iki önemli seçenektir. Ancak özellik temel alınarak yapılacak konumlandırmanın sağlayacağı rekabet avantajı, genellikle rakipler tarafından kolayca taklit edilebileceği için sürdürülebilir olmayabilmektedir. Bundan dolayı konumlandırmada özellikler temel alınıyorsa, ya bu özellikler sürdürülebilir rekabet avantajı sağlamalı ya da markanın yenilikçi karakterini desteklemelidir. Özellik temelli konumlandırmaya göre fayda temelli konumlandırma daha büyük avantajlar taşımaktadır. Ancak fayda temelli konumlandırma stratejisinde de zamanlama önemlidir. Eğer markanın fayda iddiası, rakip markalar tarafından daha önce kullanılmış ve tüketici algılarında yer bulmuş ise bu konumlandırma markayı farklılaştırmaktan uzak olacaktır (Gelder, 2008: 3132).

\section{Algı Haritalama ve Çok Boyutlu Ölçekleme}

Markaların konumlandırma veya yeniden konumlandırmaları kararları yüksek düzeyde risk içerir. İşletmelerin bu riski düşürmeleri gerekir. Algı haritalama, aşağıdaki konularda pazarlamacıların bilgilenmelerini sağlayarak bu riskin azalmasına yardımcı olur (Jain, 2000: 365):

- Rakip markaların, farklı tüketici grupları tarafından nasıl algılandığı

- Rakip markalar arasındaki benzerlik veya benzemezlikler 
Uşak Üniversitesi Sosyal Bilimler Dergisi

$2013,6 / 3$

H. H. CEYLAN

- Mevcut markanın tüketicilerin algılarında nasıl yeniden konumlandırılacağ 1

- Yeni bir markayı yerleşik bir pazarda konumlandırma

- Hedef pazar algılarına dönük pazarlama kampanyası sürecinin takip edilmesi

Algı haritalama amacıyla en çok kullanılan yöntemler; çok boyutlu ölçekleme analizi, faktör analizi, ayrıştırma analizi ve konjoint analizidir. $\mathrm{Bu}$ yöntemlerin belirli koşullarda birbirlerine göre göreceli avantaj ve dezavantajları bulunmaktadır (Gwin ve Gwin, 2003: 30). Dolayısıyla hangi yöntemin daha uygun olduğuna, çalışılan konu özelinde yapılacak değerlendirmeler sonunda karar verilmesi gerekmektedir.

Bunlar arasında önemli üstünlükleri nedeniyle en popüler olanlardan biri, çok boyutlu ölçekleme analizidir. Çok boyutlu ölçekleme analizi, kişilerin $\mathrm{m}$ boyutlu uzayda $\mathrm{n}$ tane nesneyi nasıl algıladığını grafiksel olarak sunmayı amaçlayan istatiksel bir yöntemdir. Yöntem, kişilerin nesnelere ilişkin benzerlik değerlendirmelerine dayalı olarak nesnelerin, minimum sayıda boyutla çok boyutlu uzayda gösterimine dayanmaktadır. Boyutların; araştırılan nesneler setinin kişiler tarafından algılanma ve karşılaştırılmasında dikkate alınan belirgin nesne özellikleri olduğu varsayılmaktadır (Singson, 1975: 39).

Çok boyutlu ölçekleme analizinde ortaya çıkan boyutların isimlendirilmesi, genellikle faktör analizinde olduğu gibi, araştırmacının sübjektif değerlendirmelerine göre olabilmektedir. Araştırmacılar, markaların bilinen özelliklerini dikkate alarak boyutlar hakkında değerlendirme yapmaktadırlar (NeiE, 1969: 40). Ancak zaman içinde sübjektif yöntemi tamamlamak üzere objektif yöntemler de geliştirilmiştir. Bunlar içinde en yaygın kullanılan, PROFIT (PROperty FITting) yöntemidir. $\mathrm{Bu}$ yöntemde her bir marka için özelliklere ilişkin değerlendirmeler katılımcılardan toplandıktan sonra özelliklerin algısal uzayda en iyi uyumu bulunmaya çalışılır. Burada amaç, tüketicilerin markalara ilişkin benzerlik değerlendirmelerinde hangi özelliklerin daha ağırlıklı olduğunun belirlenmesidir (Hair vd., 2006: 660).

Çok boyutlu ölçekleme analizi, p boyutlu uzayda tanımlanan nesneler arası ilişkileri boyut indirgeyerek belirlemeyi amaçlayan grafik tabanlı bir yöntemdir. Grafiksel gösterimde benzer nesnelerin birbirine yakın, benzemeyenlerin ise uzak olması beklenmektedir (Alpar, 2011: 383).

Çok boyutlu ölçekleme analizinde metrik ve metrik olmayan veriler kullanılabilmektedir. Metrik olmayan çok boyutlu ölçeklemede girdi 
verilerinin sıralı, çıktıların ise aralıklı yani metrik olacağı varsayılır. Metrik ölçeklemede ise hem girdi verilerinin hem de çıktıların metrik olacağ 1 varsayılmaktadır. Çok boyutlu ölçekleme analizinde verilerinin toplanması; cevaplayıcıların nesne çiftleri arasındaki benzerlik/benzemezlik yada tercih değerlendirmelerine dayalı olarak doğrundan olabileceği gibi nesne özelliklerine ilişkin değerlendirmelere dayalı olarak dolaylı da olabilmektedir (Nakip, 2006: 542).

Çok boyutlu ölçekleme analizi, her bir cevaplayıcı için ayrı çözüm sonuçları elde edilebilmesi ile faktör analizi ve ayrıştırma analizi gibi yöntemlerden ayrışmaktadır. Araştırmacı isterse cevaplayıcılardan elde edilen benzerlik veya tercih verilerine dayalı olarak her bir cevaplayıcıya ait alg1 haritaları oluşturulabilmektedir. Bunun yanında araştırmacı bireysel verilerin ortalamalarını alarak ortak bir algı haritası da oluşturabilir. Hangi yöntemin benimseneceği çalışma amacına bağlıdır. Çalışmada cevaplayıcıların nesneler hakkındaki genel değerlendirmeler ve bu değerlendirmelerde kullanılan boyutlar hakkında bilgi sahibi olmak amaçlanıyorsa genel çok boyutlu ölçekleme analizi, eğer bireyler arası farklılıklar ve bölümlendirme amaçlanıyorsa bireysel düzeyde çok boyutlu ölçekleme analizi tercih edilmektedir (Hair vd., 2006: 640-641).

Çok boyutlu ölçekleme analizinde elde edilen boyut sayısının uygunluğu stress değeri ile belirnebilmektedir. Uyum iyiliğinin bir ölçüsü olan stress değeri için referans değerler Tablo 1'de verilmiştir (Kalaycl, 2005: 384):

Tablo 1: Stress Değerleri ve Uyumluluk Seviyeleri

\begin{tabular}{|l|l|}
\hline Stress Değeri & Uyumluluk \\
\hline$\geq 0,20$ & Uyumsuz Gösterim \\
\hline $0,10<0,20$ & Düşük Uyum \\
\hline $0,05<0,10$ & İyi Uyum \\
\hline $0,025<0,05$ & Mükemmel Uyum \\
\hline $0,00<0,025$ & Tam Uyum \\
\hline
\end{tabular}

Çok boyutlu ölçekleme analizinde bir diğer uyum değeri de $\mathrm{R}^{2}$ değeridir. Çok boyutlu ölçekleme modelinin girdi verisi ile uyumuna gösteren $R^{2}$ değerinin en az 0,60 olması beklenmektedir. Daha yüksek $R^{2}$ değerleri daha iyi uyuma işaret etmektedir (Hair vd., 2006: 654).

Pazarlama bağlamında düşünüldügünde çok boyutlu ölçekleme analizinde her marka uzayda bir nokta ile temsil edilmektedir. Grafiksel gösterimde birbirine yakın olan markaların tüketiciler tarafından benzer 
olarak algılandığı ve bu algının oluşumunda markalara ilişkin belirli özelliklerden oluşan boyutların temel alındığı varsayılmaktadır (Ghose, 1994: 6).

Çok boyutlu ölçekleme analizi sayesinde pazarlama yöneticileri aşağıdaki konularda daha doğru değerlendirmeler yapabilirler (Gwin ve Gwin, 2003: 30):

- Markanın, kendini pazardaki diğer markalardan farklılaştıracak bir konumda olup olmadığ

- Yeni bir markanin sunumu veya mevcut markanın yeniden konumlandırılması için potansiyel fırsatların varlı̆̆

- Pazarda mevcut markalar tarafından beklentilerin tam olarak karşılanamadığı pazar bölümlerinin bulunup bulunmadığı

\section{Araştırmanın Amacı ve Önemi}

Günümüzde yaşanan yoğun rekabet nedeniyle işletmelerin hata yapma lüksleri bulunmamaktadır. Çünkü bazen küçük hatalar, işletmeler için büyük olumsuz sonuçlar doğurabilmektedir. Bu nedenle doğru karar vermek isteyen işletmeler için mevcut koşulları doğru okumak büyük önem taşımaktadır. Bu yönüyle marka konumlandırma kararlarından önce tüketicilerin markalara ilişkin mevcut algılarını belirlemek ve konumlandırma kararlarını buna göre vermek başarı şansını artıracaktır.

$\mathrm{Bu}$ çalışmada; yoğun rekabetin yaşandığı dizüstü bilgisayar markalarına ilişkin üniversite öğrencilerinin algı haritalarının belirlenmesi ve elde edilen bulgulardan hareketle çalışmaya katılanların markaları hangi boyutlara göre değerlendirdiklerinin belirlenmesi amaçlanmıştır.

\section{Araştırmanın Yöntemi}

Araştırmada öğrencilerin dizüstü bilgisayar markalarına ilişkin algı haritalarının belirlenebilmesi amacıyla çok boyutlu ölçekleme analizi kullanılmıştır. Çok boyutlu ölçekleme analizinde temel amaç nesneleri; aralarındaki benzerliklere dayalı olarak mümkün olan en az boyutla kavramsal uzayda orijinale yakın bir biçimde ortaya koymak (Kalaycı, 2005: 379) olduğundan bu çalışma tanımlayıcı bir çalışmadır.

\section{Çalışmanın Ana kütlesi ve Örneklemi}

Çalışmanın ana kütlesini Uşak Üniversitesinde eğitim gören üniversite öğrencileri oluşturmaktadır. Üniversite öğrencileri; gerek akademik gerekse iletişim ve eğlence amaçlı olarak dizüstü bilgisayarları yoğun olarak kullanmaktadırlar. Bu nedenle dizüstü bilgisayar markalarının 
Uşak Üniversitesi Sosyal Bilimler Dergisi

$2013,6 / 3$

H. H. CEYLAN

önemli hedef pazarlarından olan üniversite öğrencileri bu çalışmanın ana kütlesi olarak belirlenmiştir. Çalışmanın ana kütlesini oluşturan Uşak Üniversitesi öğrencilerinden toplam 200 öğrenci, kolayda örnekleme yöntemi kullanılarak çalışmanın örneklemi olarak belirlenmiştir. Ancak çalışma verilerinin analizi, örneklemde yer alan öğrencilerle yapılan yüz yüze anket uygulaması sonucunda eksik ve dikkatsiz doldurulan anketlerden çıkarıldıktan sonra kalan 144 anket üzerinden gerçekleştirilmiştir. Çalışma örneklemi, 84 kız, 60 erkek öğrenciden oluşmuştur.

\section{Veri Toplama Araçları}

Çalışma verilerini toplamak üzere anket formu oluşturulurken ilk olarak çalışmada yer alacak dizüstü bilgisayar markaların belirlenmesi amacıyla öğrencilerden en iyi bildikleri sekiz dizüstü bilgisayar markasını belirtmeleri istenmiştir. Elde edilen cevaplardan öğrenciler tarafından en iyi bilinen sekiz dizüstü bilgisayar markası belirlenmiştir. Belirlenen markalara çalışmada; A, B, C, D, E, F, G ve H rumuzlarıyla yer verilmiştir.

Çalışmada yer alacak dizüstü bilgisayar markaları belirlendikten sonra anket formu üç bölüm olarak tasarlanmıştır. Birinci bölümde, katılımcıların demografik özelliklerine ve dizüstü bilgisayar kullanımlarına ilişkin sorulara yer verilmiştir. İkinci bölümde benzerlikleri açısından değerlendirilmek üzere sekiz dizüstü bilgisayar markasının birbirleriyle eşleştirilmeleri ile oluşan Tablo 2'deki toplam 28 marka çiftine yer verilmiştir. Araştırmaya katılanlardan marka çiftlerini; " $7=$ Çok benzer............1= Hiç benzemez" şeklinde değerlendirmeleri istenmiştir.

Tablo 2: Benzerlikleri Açısından Değerlendirilecek Marka Çiftleri

\begin{tabular}{|l|l|l|l|}
\hline Marka Çifti & $\begin{array}{l}\text { Benzerlik } \\
\text { Puanı }\end{array}$ & Marka Çifti & $\begin{array}{l}\text { Benzerlik } \\
\text { Puanı }\end{array}$ \\
\hline $\mathrm{A} \leftrightarrow \mathrm{B}$ & & $\mathrm{C} \leftrightarrow \mathrm{E}$ & \\
\hline $\mathrm{A} \leftrightarrow \mathrm{C}$ & & $\mathrm{C} \leftrightarrow \mathrm{F}$ & \\
\hline $\mathrm{A} \leftrightarrow \mathrm{D}$ & $\mathrm{C} \leftrightarrow \mathrm{G}$ & \\
\hline $\mathrm{A} \leftrightarrow \mathrm{E}$ & $\mathrm{C} \leftrightarrow \mathrm{H}$ & \\
\hline $\mathrm{A} \leftrightarrow \mathrm{F}$ & & $\mathrm{D} \leftrightarrow \mathrm{E}$ & \\
\hline $\mathrm{A} \leftrightarrow \mathrm{G}$ & & $\mathrm{D} \leftrightarrow \mathrm{F}$ & \\
\hline $\mathrm{A} \leftrightarrow \mathrm{H}$ & & $\mathrm{D} \leftrightarrow \mathrm{G}$ & \\
\hline $\mathrm{B} \leftrightarrow \mathrm{C}$ & $\mathrm{D} \leftrightarrow \mathrm{H}$ & \\
\hline $\mathrm{B} \leftrightarrow \mathrm{D}$ & $\mathrm{E} \leftrightarrow \mathrm{F}$ & \\
\hline $\mathrm{B} \leftrightarrow \mathrm{E}$ & $\mathrm{E} \leftrightarrow \mathrm{G}$ & \\
\hline $\mathrm{B} \leftrightarrow \mathrm{F}$ & & $\mathrm{E} \leftrightarrow \mathrm{H}$ & \\
\hline
\end{tabular}




\begin{tabular}{|l|l|l|l|}
\hline $\mathrm{B} \leftrightarrow \mathrm{G}$ & $\mathrm{F} \leftrightarrow \mathrm{G}$ & \\
\hline $\mathrm{B} \leftrightarrow \mathrm{H}$ & & $\mathrm{F} \leftrightarrow \mathrm{H}$ & \\
\hline $\mathrm{C} \leftrightarrow \mathrm{D}$ & $\mathrm{G} \leftrightarrow \mathrm{H}$ & \\
\hline
\end{tabular}

Son bölümde ise her bir dizüstü bilgisayar markasının tablo 3'deki nitelikler açısından değerlendirilmesi istenmiştir. Dizüstü bilgisayar markalarına ilişkin özellikler; literatürde benzer çalışmalarda yer alan özellikler ve öğrencilerle yapılan görüşmelerde önem verdikleri dizüstü bilgisayar özellikleri dikkate alınarak belirlenmiştir.

Tablo 3: Marka Özelliklerine İlişkin Değerlendirme

\begin{tabular}{|l|l|}
\hline Özellikler & \multicolumn{1}{|c|}{ Puan } \\
\hline Kalite & \\
\hline Fiyat & \\
\hline Prestij & \\
\hline Dayanıklılık & \\
\hline Performans & \\
\hline Tasarım & \\
\hline Yenilikçilik & \\
\hline Servis & \\
\hline
\end{tabular}

\section{Verilerin Analizi ve Kullanılan İstatistiksel Teknikler}

Katılımcların nesnelere ilişkin algılarını belirlenmesinde farklı istatiksel yöntemler kullanılabilmektedir. Bunlardan bir olan faktör analizinde nesnelere ilişkin algının ölçümü, araştırmacı tarafından önceden belirlenmiş özellikler üzerinden cevaplayıcıların nesneleri değerlendirmeleri ile gerçekleştirilmektedir. Bu durum araştırmacının kendi algıları ile çalışmaya katılanları yönlendirme ihtimalini artırmaktadır. Çünkü çalışmaya katılanlar, nesneleri sadece araştırmacının belirlemiş olduğu özellikler üzerinden değerlendirmek durumunda kalmaktadırlar. Hâlbuki çok boyutlu ölçekleme analizinde, faktör analizinden farklı olarak, araştırmaya katılanlardan nesne çiftleri arasındaki benzerlikleri değerlendirmeleri istenmekte ve bu değerlendirmelerin hangi özellikler üzerinden yapıldığına ilişkin çıkarımlar yapılmaktadır. Bu da çalışmanın daha objektif olmasına katkı sağlamaktadır (Singson, 1975).

Çalışma verileri, çok boyutlu ölçekleme analizi ile ALSCAL yöntemi kullanılarak analiz edilmiştir. Çalışmada markalara ilişkin genel değerlendirmeler ve bu değerlendirmelerde kullanılan boyutların belirlenmesi amaçlanmadığı için çok boyutlu ölçekleme analizini gerçekleştirmek için ilk olarak ters kodlama yapılarak benzerlik verileri 
Uşak Üniversitesi Sosyal Bilimler Dergisi

$2013,6 / 3$

H. H. CEYLAN

benzemezlik verilerine dönüştürülmüştür. Daha sonra cevaplayıcıların Tablo 2'deki marka çiftlerine verdikleri değerlerin ortalamaları alınarak Tablo 4'te görülen tek bir girdi matrisi elde edilmiştir.

Tablo 4: Markalar Arası Ortalama Benzemezlik Matrisi

\begin{tabular}{|l|l|l|l|l|l|l|l|}
\hline A & & & & & & & \\
\hline B & 4,5 & & & & & & \\
\hline C & 4,8 & 4,8 & & & & & \\
\hline D & 4,9 & 4,8 & 4,7 & & & & \\
\hline E & 4,7 & 5,0 & 4,4 & 4,5 & & & \\
\hline F & 4,3 & 4,5 & 4,4 & 4,6 & 4,6 & & \\
\hline G & 4,5 & 4,7 & 4,9 & 4,6 & 4,9 & 4,5 & \\
\hline H & 4,1 & 4,6 & 4,5 & 4,6 & 4,5 & 4,4 & 4,8 \\
\hline
\end{tabular}

Bulgular

Öğrencilere anketin ilk bölümünde demografik soruların yanında dizüstü bilgisayar kullanımına ilişkin sorular da sorulmuştur. Buna göre; 116 öğrenci bir dizüstü bilgisayar sahip olduğunu söylerken, $B$ ve $H$ markaları sırayla 23 ve 20 öğrenci ile en çok sahip olunan dizüstü bilgisayar markaları olarak bulunmuştur. Öğrencilerin \% 68'i dizüstü bilgisayarlarını bir veya iki yıldır kullandıklarını ifade etmişlerdir. Öğrencilerin \% 84,5'i dizüstü bilgisayarlarından ya çok memnun ya da memnun olduklarını ifade etmişlerdir.

Tablo 4'teki benzerlik matrisi, SPSS 18 programına girilerek ALSCAL yöntemi ile analiz edilmiştir. Çok boyutlu ölçekleme analizi sonucu elde edilen Tablo 5'deki Stress ve $\mathrm{R}^{2}$ değerleri verinin modele uyumunun yeterli olduğunu göstermektedir. Analiz sonucu Şekil 1'de görülen dizüstü bilgisayar markalarının benzemezlik verilerine dayalı iki boyutlu uzay haritası elde edilmiştir. Algı haritası incelendiğinde B ve A ile $C$ ve E markalarının benzer olarak algılandığı görülmektedir. Nitekim Tablo 5 'te görüldüğü üzere her iki marka çiftinin her iki boyut açısından yakın değerlere sahip oldukları görülmektedir. Uzay haritasında birbirine yakın markalar arasındaki rekabetin daha fazla olduğu varsayılmaktadır. Diğer markalar arasında her iki boyut açısından olmasa da boyutlardan biri üzerinden benzerlikler söz konusudur. Örneğin D ve G'in Boyut 1 açısından oldukça farklı algılanmasına rağmen, Boyut 2 açısından oldukça benzer olarak algılandığı görülmektedir. Bir diğer tek boyut üzerinden benzerliğin G ile $B$ ve $A$ arasında Boyut 1 açısından ortaya çıktığı görülmektedir. Son olarak $\mathrm{H}$ ve $\mathrm{F}$, algı haritasında Boyut 1 açısından oldukça benzer olarak yer almışlardır. 
Uşak Üniversitesi Sosyal Bilimler Dergisi

$2013,6 / 3$

H. H. CEYLAN

Tablo 5: Markalarının Koordinatlarl ve Uyum İyiliğ $i$

\begin{tabular}{|l|l|l|l|}
\hline No & Markalar & Boyut 1 & Boyut 2 \\
\hline 1 & A & 1,3924 &, 3033 \\
\hline 2 & B & 1,4912 &, 5475 \\
\hline 3 & C & $-1,4166$ &, 6284 \\
\hline 4 & D &,- 9842 & $-1,3177$ \\
\hline 5 & E & $-1,5257$ &, 2232 \\
\hline 6 & F &, 1564 &, 1399 \\
\hline 7 & G & 1,0364 & $-1,4207$ \\
\hline 8 & $\mathrm{H}$ &,- 1500 &, 8960 \\
\hline Stress $=, 14184 \quad \mathrm{R}^{2}=, 85743$ & \\
\hline
\end{tabular}

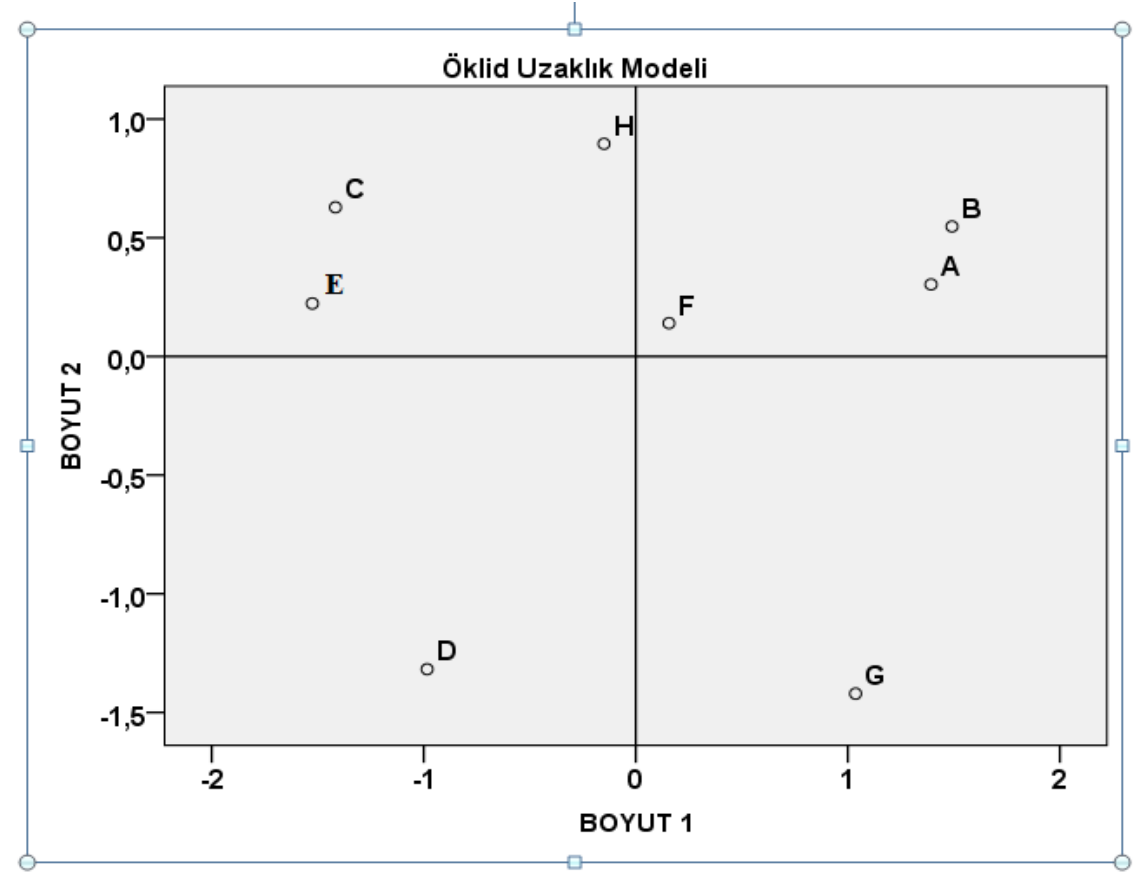

Şekil 1: Dizüstü Bilgisayar Markalarının Uzay Haritası

Cevaplayıcıların sekiz özellik üzerinden markalara ilişkin yaptıkları değerlendirmelerin ortalamaları Tablo 6'da görülmektedir. Buna göre; bütün özelliklerin ortalamaları dikkate alındığında en yüksek puana sahip dizüstü bilgisayar markasının A olduğu, bunu birbirine yakın puanlarla $\mathrm{F}, \mathrm{H}$ ve $\mathrm{B}$ markalarının izlediği görülmektedir. Ancak özellikler ayrı ayrı değerlendirildiğinde fiyat açısından A'nın en düşük puana sahip olduğu 
Uşak Üniversitesi Sosyal Bilimler Dergisi

görülmektedir. Dolayısıyla bu sonuç cevaplayıcıların A'yı fiyat açısından olumsuz olarak algıladıklarını göstermektedir. Bunun dışındaki bütün özellikler açısından A en yüksek puana sahip markadır. Ancak buna rağmen A'nın da servis konusunda kendi ortalamasının altında kaldığ görülmektedir. Bu da genel anlamda markalara ilişkin servise algının çok da olumlu olmadığını göstermektedir. Nitekim bütün markaların özelliklerinin ortalamalarına bakıldığında, fiyat ve servisinin en düşük ortalamaya sahip özellikler olduğu görülmektedir.

Tablo 6: Markaların Özelliklere göre Ortalama Puanları

\begin{tabular}{|c|c|c|c|c|c|c|c|c|c|}
\hline 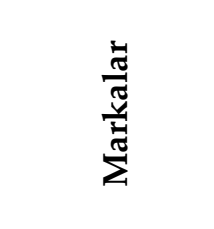 & 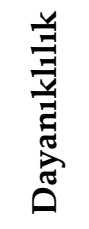 & $\stackrel{\pi}{\pi}$ & 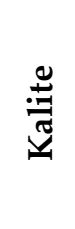 & 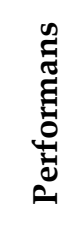 & 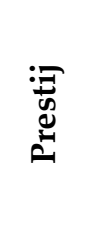 & $\sum_{\infty}^{\infty}$ & 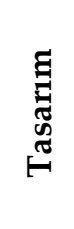 & 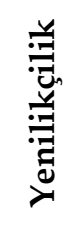 & 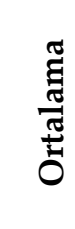 \\
\hline A & 5,34 & 3,76 & 5,58 & 5,48 & 5,38 & 4,87 & 5,41 & 5,08 & 5,11 \\
\hline $\mathbf{F}$ & 4,89 & 4,50 & 5,11 & 4,86 & 4,82 & 4,58 & 5,02 & 5,09 & 4,85 \\
\hline C & 4,49 & 4,31 & 5,07 & 4,58 & 4,14 & 3,89 & 4,40 & 4,38 & 4,40 \\
\hline B & 4,67 & 4,68 & 5,08 & 4,82 & 4,75 & 4,62 & 4,94 & 4,76 & 4,79 \\
\hline $\mathbf{E}$ & 4,25 & 4,31 & 4,30 & 4,21 & 4,06 & 4,32 & 4,03 & 4,18 & 4,20 \\
\hline G & 3,93 & 4,08 & 4,06 & 4,02 & 4,23 & 4,03 & 4,41 & 4,53 & 4,16 \\
\hline $\mathrm{H}$ & 4,86 & 4,72 & 5,26 & 4,84 & 4,92 & 4,64 & 4,75 & 4,65 & 4,83 \\
\hline D & 4,31 & 4,40 & 4,43 & 4,48 & 4,21 & 4,06 & 4,35 & 4,27 & 4,31 \\
\hline Ortalamalar & 4,59 & 4,34 & 4,86 & 4,66 & 4,56 & 4,37 & 4,66 & 4,61 & \\
\hline
\end{tabular}

Şekil 1'de elde edilen algı haritasında boyutların objektif olarak isimlendirilebilmesi amacıyla ilk olarak marka özelliklerine ilişkin cevaplayıcı değerlendirmelerinin ortalamaları alınarak Tablo 6'daki değerler elde edilmiştir. Daha sonra SPSS'de Proxscal yönteminde Tablo 4 'teki benzemezlik matrisi girdi verisi olarak girilmiş ve özelliklere ilişin ortalama değerler de kısıtlar seçeneğinde "bağımsız değişkenlerin doğrusal kombinasyonu" seçeneği ile analize dahil edilmiştir. Bu sayede boyutlar daha kolay yorumlanabilecektir. Şekil 2'de özelliklerin ortay uzaydaki konumları ve yönleri dikkate alındığında tasarım, prestij ve yenilikçilik faktörlerinin Boyut 1'i, buna karşıllk dayanıklılık, kalite, performans, servis ile birlikte fiyatın Boyut 2'yi daha iyi tanımladığı görülmektedir. Dolayısıyla Boyut 2, daha çok fonksiyonel özellikleri ortaya koyarken, Boyut 1'de estetik özelliklerin daha ağırlıklı olduğu görülmektedir. 


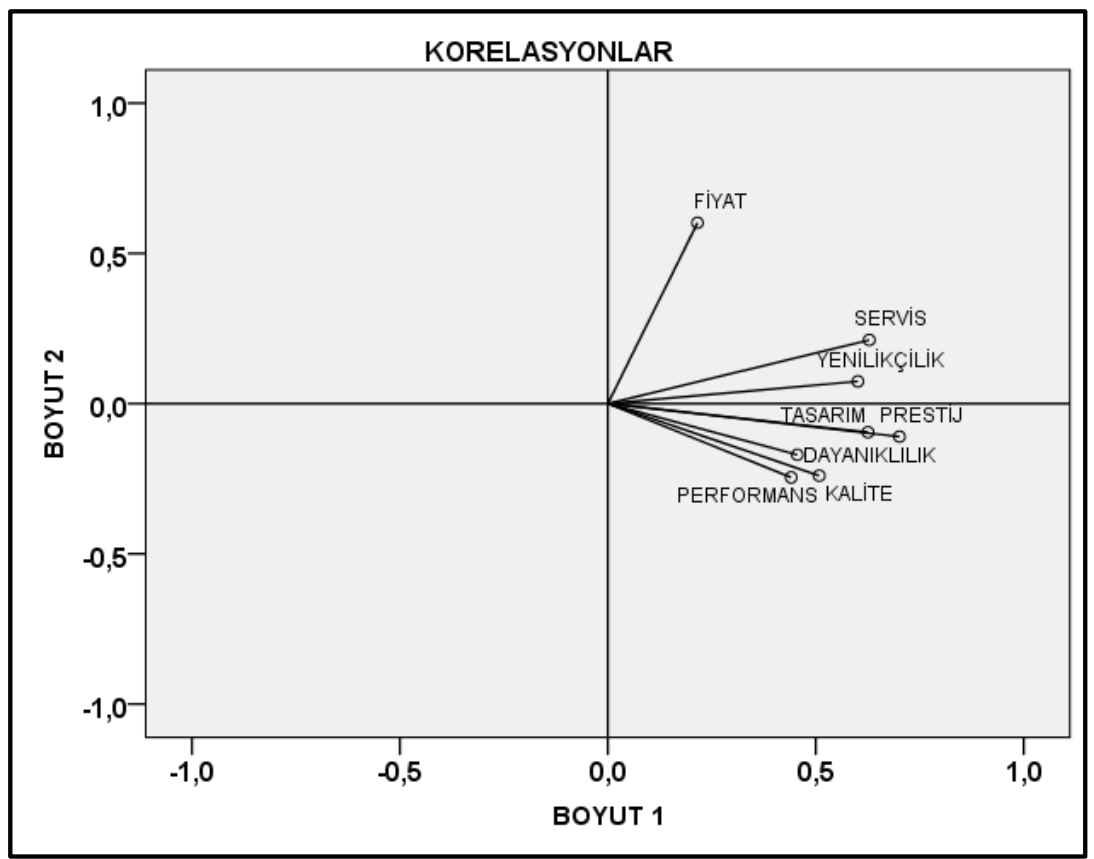

Şekil 2: Dizüstü Bilgisayar Marka Özelliklerinin Korelasyon Haritası

Şekil 1'de yer alan markaların alg1 haritaları, boyutların isimlendirilmesine ilişkin bilgiler ışığında tekrar değerlendirildiğinde A, B, $G$ ve $F$ markalarının estetik özellikler açısından diğer markalardan daha olumlu algılandıkları görülmektedir. D markasının, hem estetik özellikler hem de fonksiyonel özellikler açısından olumlu algılanmadığı, buna karşılık E ve C markalarının estetik açıdan olmasa da fonksiyonel özellikler bakımdan olumlu algılandığı görülebilmektedir.

\section{Sonuç ve Öneriler}

Yaşanan yoğun rekabet işletmeleri, verecekleri kararlarda daha dikkatli olmaya zorlamaktadır. İşletmeler için önemli kararlardan biri de markayı rakiplerden farklılaştırmayı amaçlayan marka konumlandırma kararlarıdır. Marka konumlandırma sürecinin başarısı, tüketicilerin markalara ilişkin mevcut algılarının doğru belirlenmesine bağlıdır. Pazarlama araştırmalarında markalara ilişkin tüketici algılarını belirleme en çok kullanılan yöntemlerden biri de çok boyutlu ölçekleme analizidir. Bu çalışmada da dizüstü bilgisayar markalarının önemli hedef pazarlardan biri olan üniversite öğrencilerinin markalara ilişkin algı haritalarını belirlemek üzer çok boyutlu ölçekleme analizi kullanılmıştır. 
Uşak Üniversitesi Sosyal Bilimler Dergisi

$2013,6 / 3$

H. H. CEYLAN

Çok boyutlu ölçekleme analizi sonucunda dizüstü bilgisayar markalarına ilişkin iki boyutlu algı haritası elde edilmiştir. Markala ilişkin objektif ve sübjektif değerlendirmeler sonucunda bu boyutlar, fonksiyonel ve estetik özellikler olarak isimlendirilmiştir. Bu boyutlar açısından markalar değerlendirildiğinde B ve A markaları arasındaki benzerlik dikkat çekmektedir. Bu iki marka her iki boyut açısından da benzer olarak algilanmaktadır. Buradan hareketle iki marka arasındaki rekabetin yoğun olduğu değerlendirilmektedir. Bu noktada her iki marka açısından kendini diğer markadan farklılaştıracak şekilde yeniden konumlandırmak önemli görünmektedir.

$\mathrm{F}$ ve $\mathrm{H}$ markaları da bu iki markaya her iki boyut açısından en yakın markalar olarak bulunmuştur. F markasının estetik özellikler boyutu açısından olumlu algılanması, F'nin diğer ürünlerinde sahip olduğu olumlu imajın dizüstü bilgisayar markasına transferi gibi değerlendirilebilir. Ancak tüketicilerin marka ile temasları artıkça markaya özgü değerlendirmelere dayalı olarak imaj güncellemesi yapacakları da unutulmamalıdır. Dolayısıyla F markasının, sahip olduğu mevcut olumlu algıyı sürdürmeye dönük çabalar yanında $B$ ve A markalarından farklılaşması da gerekmektedir.

Algı haritasında C ve E markalarını fonksiyonel özellikler açısından benzer ve olumlu bir algıya sahip oldukları görülmektedir. Ancak dizüstü bilgisayar gibi görünürlüğü yüksek ürünlerin tüketici tercihlerinde estetik özellikler, en az fonksiyonel özellikler kadar önemli yer tutmaktadır. Dolayısıyla bu iki markanın bu noktaya yoğunlaşmaları gerektiği ortadadır.

G marka dizüstü bilgisayarlar fonksiyonel özellikler açısından olumsuz, estetik özellikler açısından olumlu bir algıya sahip gibi görünmektedir. D markası ise hem fonksiyonel hem de estetik özellikler açısından olumsuz bir algıya sahip olduğu görülmektedir.

Markaların bazı özelliklere göre yapılan değerlendirmelerinde ortaya çıkan sonuçlar markalardan bağımsız olarak servis konusunda tüketici algılarının oldukça olumsuz olduğunu göstermektedir. Yoğun kullanım ve elektronik ürünlerinin arıza ihtimalinin yüksekliği dizüstü bilgisayarlarda servis konusunun önemini artırmaktadır. Markalar başka özellikler üzerinden farklılaşsalar da servis konusunda belirli standardı tutturmaları gerekir.

Algı haritası genel olarak değerlendirildiğinde markaların yoğun bir şekilde kümelenmediği görülmektedir. Dolayısıyla tüketicilerin dizüstü bilgisayar markalarını birbirlerinden oldukça farklı algıladıkları söylenebilir. 
Ancak bu farklılık olumlu algıya sahip markalar açısından bir avantaj olurken, diğer markalar açısından dezavantaj oluşturmaktadır.

Sonuç olarak, markalara ilişkin bu değerlendirmelerin tüketicilerin sübjektif değerlendirmeleri olduğu, gerçeklerle bire bir örtüşmeyebileceği unutulmamalıdır. Markalara ilişkin gerçekler ile tüketicilerin algıları arasında önemli farkın bulunması, işletmelerin pazarlama iletişimlerini yeniden gözden geçirme gerekliliğini ortaya koymaktadır.

\section{Kaynakça}

Aaker, D. A. (1996). Building Strong Brands. The Free Press: New York, America.

Alpar, R. (2011). Uygulamalı çok değişkenli İstatiksel Yöntemler. Detay Yayıncilik: Ankara.

Ciproano, R. (2007). Branding Insights for Small Business: Unlock The Power of Branding to Grow Your Small Business. Business Insight Press.

Gelder, S. V. (2008). Global Brand Strategy: Unlocking Branding Potential Across Countries, Cultures \& Markets. Kogan Page, London.

Ghose, S. (1994). Visually Representing Consumer Perceptions: Issues and Managerial Insights. European Journal Of Marketıng, 28(10), 5-18.

Gwin, Carol F., and Gwin, Carl R. (2003). Product Attributes Model: A Tool for Evaluating Brand Positioning. Journal of Marketing Theory and Practice, 11 (2), 30-42.

Hair, J. F., Black, W., Anderson, R., Babin, B. R. and Tahtam, R. L. (2006). Multivariate Data Analysis With Readings. Mcmillan Book Company: London.

Jain, S.C. (2000). Marketing Planning and Strategy. South Western College Publishing, Cincinatti, $\mathrm{OH}$.

Kalaycı, Ş. (2005). SPSS Uygulamalı Çok Değişkenli İstatistik Teknikleri. Asil Yayın: Ankara.

Kotler, P. (2002). Marketing Management Millenium Edition. Prentice-Hall, Inc: New Jersey.

Kotler, P. (2003). Praise for Marketing Insights from A to Z: 80 Concepts Every Manager Needs To Know. John Wiley \& Sons, Inc: New Jersey. 
Uşak Üniversitesi Sosyal Bilimler Dergisi

$2013,6 / 3$

H. H. CEYLAN

Kotler, P., and Andreasen, A. R. (1996). Strategic Marketing for Nonprofit Organization.: Prentice Hall: New jersey.

Kotler, P., Armstrong, G., Saunders, J. A. and Wong, V. (1999). Principles of Marketing. Prentice Hall Europe: New Jersey.

Lepla, F. J. and Parker, L. M. (2002). Integrated Branding: Becoming BrandDriven Through Company - Wide Action. Kogan Page: London, UK.

Nakip, M. (2006). Pazarlama Araştırmaları Teknikler ve (SPSS Destekli) Uygulamalar. Seçkin Yayınları: Ankara.

NeiE, L. A. (1969). The Use of Nonmetric Multidimensional Scaling in Marketing Analysis. Journal of Marketing, 33(4), 37-43.

Singson, R. L. (1975). Multidimensional Scaling Analysis of Store Image and Shopping Behavior. Journal of Retailing, 51(2). 